\title{
Arginase Inhibitory, Antioxidant Activity and Pharmacognosy Study of Sterculia macrophylla Vent. Leaves
}

\author{
Rini Prastiwi ${ }^{1,2}$, Berna Elya $^{1{ }^{1 *},}$, Rani Sauriasari ${ }^{3}$, Muhammad Hanafi $^{4,5}$, Yesi Desmiaty $^{5}$
}

\section{Rini Prastiwi ${ }^{1,2}$, Berna Elya ${ }^{1{ }^{*}}$, , Rani Sauriasari ${ }^{3}$, Muhammad Hanafi ${ }^{4}$, Yesi Desmiaty ${ }^{5}$}

\section{'Department of Pharmacognosy- Phytochemistry, Faculty of Pharmacy Universities Indonesia, Depok 16424, West Java, INDONESIA. \\ ${ }^{2}$ Department of Pharmacognosy- Phytochemistry, Faculty of Pharmacy and Science Muhammadiyah Prof. Dr. Hamka University, 1340 Jakarta, INDONESIA. \\ ${ }^{3}$ Department of Pharmacology, Faculty of Pharmacy Indonesia University, Depok 16424, West Java, INDONESIA. ${ }^{4}$ Research Center for Chemistry, Indonesian Institute of Science, Serpong (LIPI) INDONESIA. \\ ${ }^{5}$ Department of Pharmacognosy- Phytochemistry, Faculty of Pharmacy Universitas Pancasila, Depok, West Java, INDONESIA. \\ Correspondence \\ Berna Elya}

Department of PharmacognosyPhytochemistry, Faculty of Pharmacy Universitas Indonesia, Depok, West Java, INDONESIA.

Phone no : +62 217270031

E-mail: berna.elya@gmail.com

\section{History}

- Submission Date: 23-01-2018.

- Review completed: 04-03-2018;

- Accepted Date: 25-08-2018

\section{DOI : 10.5530/pj.2018.6.188}

Article Available online http://www.phcogj.com/v10/i6

\section{Copyright}

(c) 2018 Phcog.Net. This is an openaccess article distributed under the terms of the Creative Commons Attribution 4.0 International license.

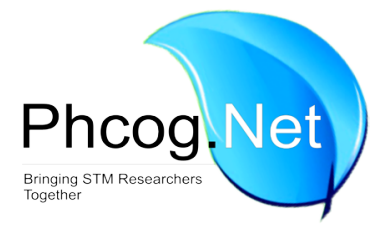

\begin{abstract}
Objective: The purpose of this study was to investigate the arginase inhibitory activity, antioxidant activity, and also pharmacognostical study of Sterculia macrophylla leaves. The main component of genus Sterculia was flavonoid that was well known to demonstrate arginase inhibitory activity. Methods: Sample was extracted gradually using n-hexane, ethyl acetate, and methanol solvents, subsequently. The n-hexane, ethyl acetate, and methanol extract were determined for their arginase inhibitory activity. The most active extract was methanol extract. This extract was determined for its antioxidant activity, arginase inhibitory activity, identification of chemical compound, chromatogram profile and determined the content of total flavonoid. The leaves and powder of Sterculia macrophylla were identified with microscopic and macroscopic evaluation. Results: The most active extract was methanol extract with $\mathrm{IC}_{50} 114,659 \mu \mathrm{g} / \mathrm{mL}$ for arginase inhibitory activity and $I C_{50} 78.47 \mu \mathrm{g} / \mathrm{mL}$ for DPPH scavenging activity. The secondary metabolite of methanol extract presence compound of alkaloid, flavonoid, tannin, terpene, and glycoside. The total flavonoid content was $141.10 \mathrm{mg} / \mathrm{gram}$ extract. The star-shape trichoma was identified as a specific fragment. Conclusion: The methanol extract of Sterculia macrophylla showed activity as arginase inhibitor and antioxidant. Key words: Arginase, Antioxidant, Flavonoid, Pharmacognostical, Sterculia macrophylla.
\end{abstract}

\section{INTRODUCTION}

Endothelial cell dysfunction (ECD) is a generic term that indicates dysregulation of endothelial cell function, including a decreased function of endothelial cells, vasodilation, impaired proliferative capacity, angiogenic properties, impaired function, and prevention of white blood cells from adhesion. Some of the factors that contribute to this including smoking, high blood pressure, diabetes, high cholesterol, obesity, hyperglycemia and genetic factors. ${ }^{1-5}$ The diseases due to endothelial function disorders are aging, diabetes, hypertension, arthritis, and atherosclerosis. ${ }^{6-10}$ Arginase (L-arginine ureahydrolase, or amidinohydrolase) is the hydrolytic enzyme responsible for converting arginine into ornithine and urea., ${ }^{411}$ Arginase plays an important role in nitrogen metabolism. The role of arginase activity in influence the balancing of NO production in the body makes arginase as one of the prospective therapeutic targets for endothelial disease disorders. ${ }^{12-14}$ Previous literature was showed that apigenin, isovitexin and vitexin inhibit arginase less than 50\%. Galangin and quercitrin 50-70\% inhibition. While isoquercitrin, isoorientin, and orientin $70-75 \%$. The best inhibition was fisetin (87\%), luteolin (83\%), quercetin (83\%) and, 7.8-dihydroxyflavone (80\%). Flavonoid Fisetin has a higher arginase inhibition capability of $4 \mathrm{x}$ compared with quercetin and 10x compared with luteolin. The substitution of the hydroxyl group at position 3 increases the activity of the arginase inhibitor, while in position five is not. Quercetin $2 \mathrm{x}$ is more potent than luteolin because of substitution at number 3 by hydroxyl groups..$^{15}$ Scutellaria indica (family Labiatae) Flavonoids compounds are 5,7dihydroxy-8,20-di-methoxyflavanone and 5,20,50trihydroxy-7,8-dimethoxy-flavanone, exhibiting inhibitory activity of each arginase of $\mathrm{IC}_{50} 25,1(\mu \mathrm{M})$ and $11.6(\mu \mathrm{M})$, while for positive control with Piceatannol-30-ObD-glucopyranoside (PG) of 1.0 $(\mu \mathrm{M}) .{ }^{16}$ Cecropia pachystachya compound Chlorogenic acid, catechin, epicatechin and isoquercitrin can inhibit above $50 \%$ at $20 \mu \mathrm{M}$. Orientin IC50 is $16 \mu \mathrm{M}$, while $\mathrm{IC}_{50}$ for ethyl acetate and methanol soluble containing approximately $24 \%$ content orientin of $48 \mu \mathrm{g} / \mathrm{mL} .{ }^{17}$ Saururus chinensis content 7-Hydroxysauchinone compounds have $\mathrm{IC}_{50}$ of $89.6 \mu \mathrm{M}$ while compound C-7 of sauchinone have arginase inhibition activity amounted to $61.4 \mu \mathrm{M} .{ }^{18}$ The arginase inhibitor activity of the best of the three plants (A. altilis, F. exasperata, K. africana) showed that $A$. altilis at concentrations of 500 and $750 \mathrm{mg} / \mathrm{mL}$ did not show significant differences with the positive control catechin. From the experiment showed that the highest levels of flavonoids were in A. altilis ${ }^{19}$ Caesalpinia sappan Lignum has activity as arginase inhibitor with $\mathrm{IC}_{50} 36.82 \mu \mathrm{g} / \mathrm{ml}$.
Cite this article: Prastiwi R, Elya B, Sauriasari R, Hanafi M, Desmiaty Y. Arginase Inhibitory, Antioxidant Activity and Pharmacognosy Study of Sterculia macrophylla Vent. Leaves. Pharmacog J. 2018;10(6):1109-13. 
Based on literature study found that flavonoid compound has an activity of arginase inhibitor. It becomes attractively researched.

One genus of plants that contain flavonoid compounds is the genus of Sterculia. Sterculia macrophylla Vent. is a native plant of Indonesia, which many encountered in the territory of Indonesia. The literature study confirms that the most natural product of the genus Sterculia is flavonoids. These results also confirm that flavonoid plays a significant role in chemotaxis. Flavonoids in S. macrophylla are flavones, flavones C-glycosides, flavonols, flavans, isoflavones, isoflavan, and anthocyanins. The phenolic compounds such as phenolic acids, phenyl propanoid, coumarin, lignans and lignin content far less than the flavonoids. ${ }^{20}$ The other metabolites in the genus of Sterculia include terpenoids, steroids, alkaloids, sugars and fatty acids. Wood, leaves, fruits, seeds and roots from Sterculia species traditionally widely used in various countries for treating various diseases, including gastrointestinal diseases, diabetes, respiratory-related diseases and skin diseases. Also, based on studies of the genus Sterculia has been studied and has activity as antimicrobial, anti-inflammatory, antioxidant, anticancer ${ }^{20}$ and malaria. ${ }^{21}$

S. macrophylla was used as an aphrodisiac in Java. ${ }^{22}$ This aphrodisiac effect could be related to arginase inhibitory activity because the increase of arginase activity has been implicated in erectile dysfunction. ${ }^{23}$ Based on our literature study, pharmacognostical, arginase inhibitory effect and antioxidant activity of Sterculia macrophylla leaves have never been studied before. For this reason, the present work is design to investigate pharmacognostical, and to evaluate arginase inhibitory effect and antioxidant activity of $S$. macrophylla leaves.

\section{MATERIALS AND METHODS}

\section{Materials}

Sterculia macrophylla Vent. plant leaves. Collected in February 2017 from Botanical Garden of Bogor and determined in Botany Herbarium Research Institute, Cibinong, West Java. The solvents used in the study were n-hexane, ethyl acetate, and methanol purchased from local suppliers. KLT plate (Merck, Germany), silica gel 60 (Merck, Germany), aqua bidestilata, arginase enzymes (Sigma, Singapore), nor-NOHA standard (Cayman, USA), L-arginine (Sigma, Singapore), maleic acid (Sigma, Singapore), manganese sulfate (Sigma, Singapore), urea assay kits (Quantichrom ${ }^{\circ}$ Bioassay, United States), dimethyl sulfoxide (Merck, Germany), methanol pro analysis (Merck, Germany ), ethyl acetate pro-analysis (Merck, Germany), n-hexane pro analysis (Merck, Germany), proliferated pro analysis (Merck, Germany). Other ingredients for identification of the compound and the identification of powdered microscopic.

\section{Macroscopic and microscopic identification}

Leaves are identified in macroscopic shape, margins, color, tip, a base of the leaves. Identification of the microscopic was done on the leaf powder to know the fragment of the identifier. Studies of morphological plants were observed based on the description given in Evans WCand Indonesian Herb Pharmacopoeia. ${ }^{24-25}$ Organoleptic characters were observed, noted and photographs were taken in the original environment.

\section{Extraction}

The extraction was done by maceration method using n-hexane, ethyl acetate, and methanol solvent. Preliminary extraction for screening was done with $20 \mathrm{~g}$ of leaf powder with solvent $200 \mathrm{~mL}$. The extract was dried with a vacuum of a rotary evaporator at a temperature of $50^{\circ} \mathrm{C}$ and then continued to dry in water bath a temperature of $50^{\circ} \mathrm{C}$. The extract obtained tested the activity of arginase inhibitor.

\section{Preparation of extracts}

The initial test of arginase inhibition activity of the three extracts using a concentration of $100 \mathrm{ppm}$. Extract S. macrophylla $(50 \mathrm{mg}$ ) was added DMSO $400 \mu \mathrm{L}$ shake until dissolved and added with aqua bidestillata to $5.0 \mathrm{ml}$. Then $1 \mathrm{ml}$ of this solution was put in the vortex tube and added with aqua bidestillata up to $2 \mathrm{~mL}$. $90 \mu \mathrm{L}$ was taken into the micro tube and was added by aqua bidestillata up to $1 \mathrm{~mL} .10 \mu \mathrm{L}$ of this solution was added to each sample. The variation concentration to determined $\mathrm{IC}_{50}$ are $10,40,70,100,130$, and $160 \mathrm{ppm}$.

\section{Arginase activity}

Identify of the arginase inhibitory activity by using the procedure contained in the kit with slight modification. Ten (10) $\mu \mathrm{L}$ samples (extract), $15 \mu \mathrm{L}$ enzyme solution, and $25 \mu \mathrm{L} \mathrm{L}$-arginine solution were added to the well, shake. The mixture was incubated for $30 \mathrm{~min}$ at $37^{\circ} \mathrm{C}$, then each sample was added the mixture of reagents A and B $(100 \mu \mathrm{L})$ from the urea kit, shake and incubated at room temperature for $60 \mathrm{~min}$. The result was measured at $430 \mathrm{~nm}$. The positive control was performed under the same conditions. nor-NOHA used as positive control. The experiments were performed in triplicate.

\section{Antioxidant activity}

Antioxidant activity of methanol extract was evaluated using DPPH scavenging ability assay, which was conducted in a 96-well plate according to previously used method Zhang lu et al. ${ }^{26}$ with slight modification. Samples in different concentrations (100, 250, 500, 1000, 1500, 2000 ppm) and $0.114 \mathrm{mM}$ DPPH solution $180 \mu \mathrm{L}$ in methanol were added to each well. Absorbance at $517 \mathrm{~nm}$ was read after $30 \mathrm{~min}$ of reaction in the dark with a micro-plate reader. The scavenging ability (\%) was calculated as follows:

$$
\text { Scavenging ability }(\%)=x 100 \%
$$

AC was the absorbance of control (without sample), AS is the absorbance of sample. Ascorbic acid was used as positive standard. All tests were performed in triplicate. The concentration of samples resulting in 50\% inhibition on DPPH $\left(\mathrm{IC}_{50}\right.$ value) were calculated.

\section{Determination of total flavonoids}

Determination of flavonoids content was measured on extracts that had the highest inhibition. The method by Chang et al. with slight modification. ${ }^{27}$ Extract $(200 \mathrm{mg}$ ) added ethanol $96 \%$ pa to $25 \mathrm{ml}$. From this sample solution is taken $0.5 \mathrm{~mL}$, then added with $1.5 \mathrm{ml}$ of ethanol $96 \% \mathrm{pa}, \mathrm{AlCl}_{3}$ p $10 \%, 0.1 \mathrm{~mL}$, Na-acetate $1 \mathrm{M}$, and, $2.8 \mathrm{~mL}$ aqua destilata. The total volume of the solution is $5 \mathrm{~mL}$. Shake this solution and then incubated at room temperature for $30 \mathrm{~min}$. The absorbance of this solution measurement using UV-Vis spectrophotometer at $437 \mathrm{~nm}$. The control used is quercetin standard.

\section{Phytochemical screening}

The identification of content compound in the extract were carried out on the most active extract (methanol). The extracts was subjected to preliminary phytochemical investigation for the detection of following compounds; terpenoids, glycosides, flavonoids, alkaloids, tannins, anthraquinones, and saponins. The procedures described by Indonesian Herb Pharmacopoeia and Harborne. ${ }^{28}$

\section{Chromatographic Profile}

Thin layer chromatographic (TLC) profile evaluated of S. macrophylla leaves extract (methanol) using silica gel 60 F254 TLC plates for the chromatographic profile. The extract was dissolved in methanol. The mobile phases for the plates developed were chloroform-acetone- 
formic acid (7:2:1). The plates were dried and observed under visible light and ultraviolet light $366 \mathrm{~nm}$, and by spraying with $10 \% \mathrm{AlCl}_{3}$. The retention factor (Rf) value was calculated. ${ }^{28}$

\section{RESULT}

\section{Microscopic and macroscopic}

Leaves are green, slightly bitter and having characteristic odor. These are ovate shape, pinnatifid, acuminate apex, crenate, cordate base and $25-40 \mathrm{~cm}$ in length, $20-30 \mathrm{~cm}$ in width. The microscopic and macroscopic fragment were show in Figure 1.

\section{Determination of flavonoid levels}

Quercetin levels were calculated as total flavonoid levels in the sample. From the calculation of quercetin standard curve, there is a linear correlation between absorbance and concentration with linear regression equation $y=0,02448 x-0,2847$ and value of relation coefficient $(r)=0$, 9999. Based on the measurement results, the average value of flavonoids in each gram of extract was $141.10 \mathrm{mg} \pm 0.712$.

\section{Arginase activity}

The preliminary study on arginase activity of three extracts. Based on the results obtained the active extract is methanol. The study of arginase

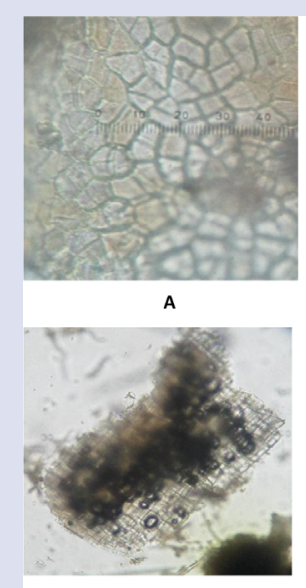

D

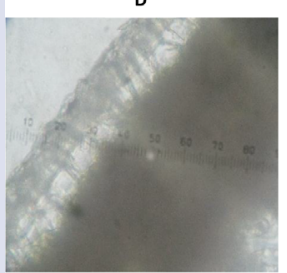

G

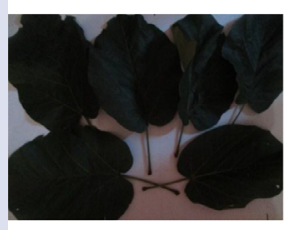

$\mathbf{J}$

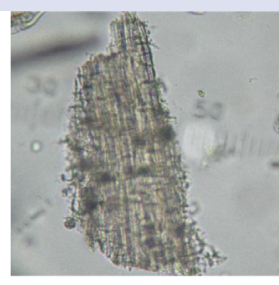

B

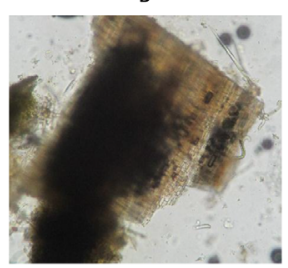

E

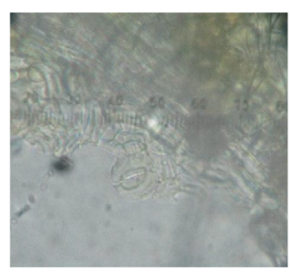

H
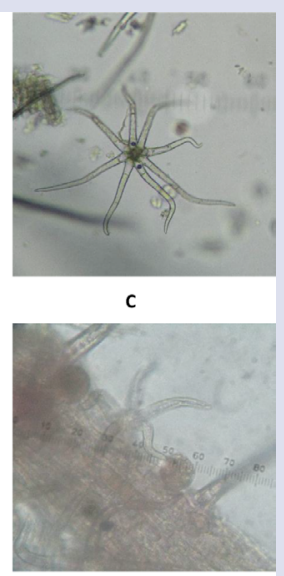

F

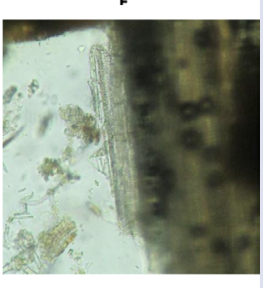

।
Figure 1: Macroscopic and Microscopic of S. macrophylla leaves powder. $\mathrm{A}=$ Pharenchym, $\mathrm{B}=$ Parenchym, $\mathrm{C}=$ Star shape trichoma, $\mathrm{D}=$ Parenchym, $\mathrm{E}=$ Cortex, $\mathrm{F}=$ Star shape trichoma on parenchym, $\mathrm{G}=$ Epidermis, $\mathrm{H}=$ Stomata, I= Phloem, J= Leaves $\mathrm{S}$. macrophylla. activity performed on a methanol extract obtained $\mathrm{IC}_{50} 97.25 \mathrm{ppm}$, while the value of $\mathrm{IC}_{50}$ for nor-NOHA as a positive control is $3.77 \mathrm{ppm}$. The result on arginase activity showed in Table 1.

\section{Antioxidant activity}

The antioxidant activity test was performed using DPPH assay. The following results are obtained. The result of antioxidant activity on the Table 2 .

The $\mathrm{IC}_{50}$ of methanol extract was $78,47 \mathrm{ppm}$, while vitamin $\mathrm{C}$ as a positive control was $2.23 \mathrm{ppm}$.

\section{Phytochemical screening}

Phytochemical screening showed presence of flavonoids, glycosides, alkaloids, tannins, terpenes, and saponins and negative to antraquinone. Here is the results in Table 3.

\section{Chromatographic Profile}

The chromatographic profile had 9 spots, and the spot no 4 ( $R f 0.43$ ) have Rf value with standard quercetin. The result was displayed in Table 4.

Table 1: Average inhibition arginase of extract methanol.

\begin{tabular}{cccc}
\hline $\begin{array}{c}\text { Concentration } \\
(\mathrm{ppm})\end{array}$ & $\begin{array}{c}\text { Average inhibition } \\
(\%)\end{array}$ & $\mathrm{SD}$ & $\begin{array}{c}\mathrm{IC}_{50} \\
(\mathrm{ppm})\end{array}$ \\
\hline 10 & 25,4985 & $\pm 2,79$ & \\
70 & 34,9908 & $\pm 0,99$ & \\
100 & 44,5485 & $\pm 2,95$ & 97,25 \\
130 & 57,7809 & $\pm 10,69$ & \\
160 & 81,9962 & $\pm 2,11$ & 3,77 \\
\hline
\end{tabular}

Table 2: Antioxidant activity of extract methanol.

\begin{tabular}{cccc}
$\begin{array}{c}\text { Concentration } \\
(\mathrm{ppm})\end{array}$ & Antioxidant activity & $\mathrm{Sd}$ & $\mathrm{IC}_{50}$ \\
\hline 10 & 11,6602 & $\pm 2,13$ & \\
25 & 19,7806 & $\pm 3,53$ & \\
50 & 43,3889 & $\pm 3,19$ & 78,47 \\
100 & 78,6366 & $\pm 2,82$ & \\
150 & 85,5816 & $\pm 0,27$ & \\
200 & 88,3613 & $\pm 1,84$ & \\
Vitamin C & & & 2,23 \\
\hline
\end{tabular}

Table 3: Phytochemical screening of extract methanol.

\begin{tabular}{cc}
\hline Chemical Constituent & Result \\
\hline Alkaloids & + \\
Flavonoids & + \\
Terpens & + \\
Tannins & + \\
Glycosides & + \\
Anthraquinones & - \\
\hline
\end{tabular}

Note $+=$ Presence

$=$ Absence 
Table 4: Chromatographic profile of extract methanol.

\begin{tabular}{|c|c|c|c|c|c|}
\hline Extract & Solvent system & Total spot & $\mathrm{Rf}$ & UV365 & $\mathrm{AlCl}_{3} 10 \%$ \\
\hline \multirow[t]{9}{*}{ Methanol extract } & \multirow{9}{*}{$\begin{array}{c}\text { Chloroform: } \\
\text { acetone:formic acid }\end{array}$} & \multirow[t]{9}{*}{9} & $\operatorname{Rf} 1=0.1$ & Rf $1=$ light blue & Rf $3=$ yellow \\
\hline & & & $\mathrm{Rf} 2=0.21$ & Rf 2 = yellow & Rf $4=$ yellow \\
\hline & & & $\mathrm{Rf} 3=0.35$ & Rf 3 = yellow & Rf 5 = yellow \\
\hline & & & $\operatorname{Rf} 4=0.43$ & Rf $4=$ yellow & \\
\hline & & & Rf $5=0.5$ & Rf $5=$ light blue Rf $6=$ & \\
\hline & & & Rf $6=0.53$ & red & \\
\hline & & & $\operatorname{Rf} 7=0.7$ & $\mathrm{Rf} 7=\mathrm{red}$ & \\
\hline & & & Rf $8=0.9$ & Rf $8=$ red & \\
\hline & & & quercetin $=0.43$ & quercetin = yellow & quercetin $=$ yellow \\
\hline
\end{tabular}

\section{DISCUSSION}

Phytochemical screening result showed that The methanol extracts contain flavonoids, glycosides, alkaloids, tannins, terpenes and saponins. Flavonoids were known have arginase inbitory activity. ${ }^{15}$ The high content of flavonoid compounds in methanol extract provides the possibility that these flavonoids have a role as an arginase inhibitor. The catechol group in flavonoid possibly interacts with one of arginase site such as Asp 129. ${ }^{29-30}$ From the chromatographic profile, we can see that methanol extract of $S$. macrophylla positively contain quercetin, one of arginase inhibitor. ${ }^{15}$ In the preliminary experiment, the most active extract was methanol extract. The inhibitory potency of methanol extract against arginase II activity is lower than nor-NOHA, but with IC50 114,659 $\mu \mathrm{g} / \mathrm{mL}$ is a natural moiety from natural medicinal plants that inhibit arginase activity would be useful for the development of pharmaceutical natural compounds. Antioxidants can inhibit free radicals and prevent from various degenerative diseases. The ability to donate electrons from natural materials can be measured by decolorization of the DPPH solution. The method is based on scavenging of DPPH through the addition of a radical species. The rate of color change is proportional to the concentration and potency of antioxidants. A large reduction in the absorbance of the reaction mixture showed significant free radical scavenging activity on the tested compound. ${ }^{19} \mathrm{NO}$ is a free radical with a short half-life $(<30 \mathrm{~s})$ and its independent action may cause neuronal damage, especially in conjunction other ROS such as superoxide radical to form peroxynitrite radical. ${ }^{31}$ This study exhibited that methanol extract of $S$. macrophylla has good arginase inhibitory activity and antioxidant activity.

\section{CONCLUSION}

The methanol extract has $\mathrm{IC}_{50} 114,659 \mu \mathrm{g} / \mathrm{mL}$ for arginase inhibitory activity and $\mathrm{IC}_{50} 78.47 \mu \mathrm{g} / \mathrm{mL}$ for $\mathrm{DPPH}$ scavenging activity. The secondary metabolite of methanol extract presence compound of alkaloids, flavonoids, tannins, terpenes, and glycosides. The total flavonoid content was $141.10 \mathrm{mg} / \mathrm{gram}$ extract. The star-shape trichoma was identified as a specific fragment.

\section{CONFLICT OF INTEREST}

We declare that we have no conflict of interest.

\section{ACKNOWLEDGEMENT}

This work was supported by PITTA Grant 2017, Directorate of Research and Community Engagement, Universitas Indonesia.

\section{ABBREVIATIONS}

N-hidroksi-nor-L-arginin: nor-NOHA; Sterculia macrophylla: S. macrophylla.

\section{REFERENCES}

1. Kolluru GK, Bir SC, Kevil CG. Endothelial Dysfunction and Diabetes : Effects on Angiogenesis, Vascular Remodeling, and Wound Healing. 2012.

2. The Application of Droplet Counter-Current for the Separation of Acidic Glycolipids1 Chromatography ( DCC ) Abbreviations. J Biochem. 1981;90(1):247-54.

3. Bagnost T, Ma L, Da Silva RF, Rezakhaniha R, Houdayer C, Stergiopulos N, et al. Cardiovascular effects of arginase inhibition in spontaneously hypertensive rats with fully developed hypertension. Cardiovasc Res. 2010;87(3):569-77.

4. Steppan J, Nyhan D, Berkowitz DE. Development of novel arginase inhibitors for therapy of endothelial dysfunction. Front Immunol. 2013;4:1-6.

5. Yang L, Lewis CM, Chandrasekharan UM, Kinney CM, Dicorleto PE, Kashyap VS. Arginase Activity Is Increased by Thrombin: A Mechanism for Endothelial Dysfunction in Arterial Thrombosis. 2006;203(6):817-26.

6. Choi S, Park C, Ahn M, Hwa J, Shin T. Acta Histochemica Immunohistochemical study of arginase 1 and 2 in various tissues of rats. Acta Histochem. 2012; 114(5):487-94

7. Shin W, Cuong TD, Lee JH, Min B, Jeon BH, Lim HK. Arginase Inhibition by Ethylacetate Extract of Caesalpinia sappan Lignum Contributes to Activation of Endothelial Nitric Oxide Synthase. 2011;15(3):123-8.

8. El-bassossy HM, El-fawal R, Fahmy A. Mechanisms of Vascular Dysfunction in Diabetes Arginase inhibition alleviates hypertension associated with diabetes: Effect on endothelial dependent relaxation and NO production Mechanisms of Vascular Dysfunction in Diabetes.Vascul Pharmacol. 2012;57(5-6):194-200.

9. Prati C, Berthelot A, Kantelip B, Wendling D, Demougeot C. Treatment with the arginase inhibitor Nw-hydroxy-nor-L-arginine restores endothelial function in rat adjuvant-induced arthritis. Arthritis Res Ther. 2012;14(3):130.

10. Prati C, Demougeot C, Guillot X, Godfrin-valnet M, Wendling D. Endothelial dysfunction in joint disease. Jt Bone Spine. 2014;81(5):386-91.

11. Caldwell RB, Toque HA, Narayanan SP, Caldwell R. Arginase: An old enzyme with new tricks. Trends Pharmacol Sci. 2015;36(6):395-405.

12. Bakker W, Eringa EC, Sipkema P. Endothelial dysfunction and diabetes: Roles of hyperglycemia , impaired insulin signaling and obesity. 2009;335(1):165-89.

13. Moretto J, Guglielmetti A, Tournier-nappey M, Martin H, Prigent-tessier A, Marie C, et al. Effects of a chronic $L$-arginine supplementation on the arginase pathway in aged rats. EXG. 2017; 90:52-60.

14. Pernow J, Jung C. Arginase as a potential target in the treatment of cardiovascular disease : reversal of arginine steal. 2013;98(3):334-43.

15. Correa L, Balduíno M, Maquiaveli C, Santos-filho OA, Roberto E. Dietary flavonoids fisetin, luteolin and their derived compounds inhibit arginase, a central enzyme in Leishmania ( Leishmania) amazonensis infection. Food Chem. 2013;141(3):2253-62

16. Kim SW, Cuong TD, Hung TM, Ryoo S, Lee JH, Min BS. Arginase II inhibitory activity of flavonoid compounds from Scutellaria indica. Arch Pharm Res. 2013;36(8):922-26.

17. De Mello E, Roberto E, Maquiaveli C, Sousa E, Alves S, Francisco J, et al Phytochemistry Leishmanicidal activity of Cecropia pachystachya flavonoids: Arginase inhibition and altered mitochondrial DNA arrangement. 2013;89:71-7.

18. Lim CJ, Cuong D, Hung M, Ryoo S, Lee JH. Arginase II Inhibitory Activity of Phenolic Compounds from Saururus chinensis. 2012;33(9):8-11.

19. Akanni OA, Owumi SE. In vitro studies to assess the antioxidative, radical scavenging and arginase inhibitory potentials of extracts from $A$ rtocarpus altilis, Ficus exasperate and K igelia africana. Asian Pac J Trop Biomed. 2014;4(1):492-9.

20. El-Sherei MM, Ragheb AY, Kassem MS, Marzouk MM, Mosharrafa SA, Saleh NM. Phytochemistry, biological activities and economical uses of the genus Sterculia and the related genera: A review. Asian Pacific Journal of Tropical Disease. 2016;6(6):492-501.

21. Nick $A$, Rali T, Sticher O. Biological screening of Traditional Medicinal Plants in Papua New Guinea. Journal of Ethnopharmacology. 1995;49(3):147-56. 
22. Orisakeye OT, Olugbade TA. Epicathecin and Procyanidin B2 in the Stem and Root bark of Sterculia tragacantha Lindl (Sterculiaceae). Med Chem. 2014;4(2):334-7.

23. Oboh G, Ademiluyi AO, Ademosun AO, Olasehinde TA, Oyeleye SI, Boligon AA, et al. Phenolic extract from Moringa oleifera leaves inhibits key enzymes linked to erectile dysfunction and oxidative stress in Rats' Penile Tissues. Biochemistry Research International. 2015;1-8.

24. Evans WC. Trease and Evans Pharmacognosye. 15th ed. Edinburgh London, New York, Philadelphia, St Louis, Sydney Toronto: WB Saunders. 2000.

25. Farmakope Herbal Indonesia. 1st ed. Jakarta: Departemen Kesehatan Republik Indonesia (Department of Health of RI). 2008.

26. Zhang L, Tu Z, Yuan T, Wang H, Xie X, Fu Z. Antioxidants and a -glucosidase inhibitors from Ipomoea batatas leaves identified by bioassay-guided approach and structure-activity relationships. Food Chem. 2016;208:61-7.
27. Chang C, Yang M, Wen H, Chern J. Estimation of Total Flavonoid Content in Propolis by Two Complementary Colorimetric Methods. 2002;10(3):178-82

28. Harborne J. A Guide to Modern Techniques of Plant Analysis. Phytochemical Methods. Chapman and Hall London. 1998.

29. Pudlo M, Demougeot C, Girard-Thernier C. Arginase Inhibitors: A Rational Approach Over One Century. Medicinal Research Reviews. 2017;37(3):1-40.

30. Girard-Thernier C, Pham TN, Demougeot C. The promise of plant-derived substances as inhibitors of arginase. Mini Rev Med Chem. 2015;15(10):798-808.

31. Belló-klein A, Oboh G, Rosa M, Schetinger C. Effect of dietary supplementation of ginger and turmeric rhizomes on angiotensin-1 converting enzyme (ACE) and arginase activities in L-NAME induced hypertensive rats. J Funct Foods. 2015;17:792-801.

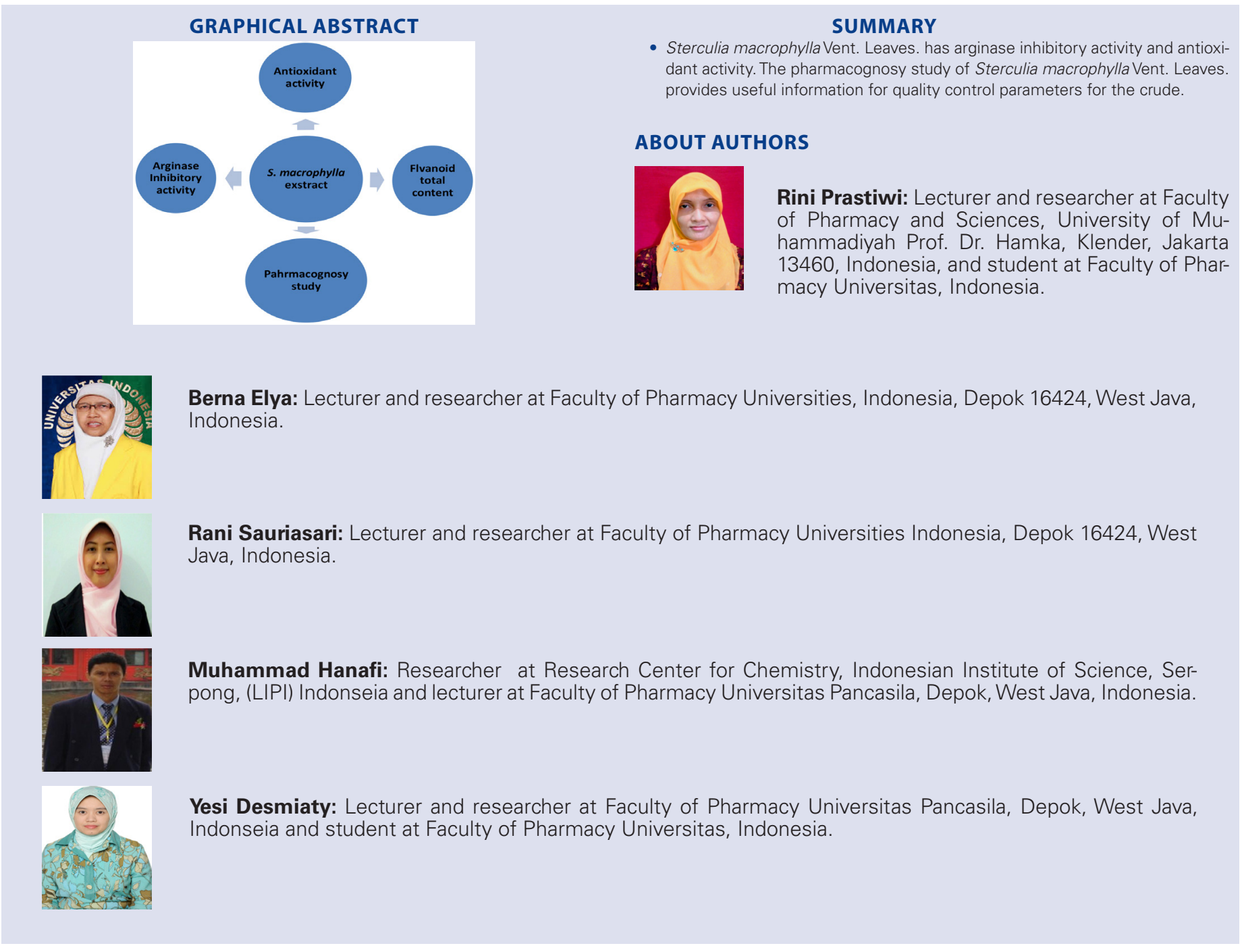

Cite this article: Prastiwi R, Elya B, Sauriasari R, Hanafi M, Desmiaty Y. Arginase Inhibitory, Antioxidant Activity and Pharmacognosy Study of Sterculia macrophylla Vent. Leaves. Pharmacog J. 2018;10(6):1109-13. 